\title{
Immunodiagnosis of Systemic Lupus Erythematosus (SLE) in a Tertiary Care Hospital
}

\author{
Latha Ragunathan ${ }^{1 *}$, Anandi Chidambaram ${ }^{2}$, Kavitha Kannaiyan ${ }^{1}$ and Chidambaram $\mathbf{N}^{3}$ \\ ${ }^{1}$ Dept Of Microbiology, Aarupadai veedu medical college \& hospital, Pondicherry India \\ ${ }^{2}$ Dept Of Microbiology, Vinayaka Missions Medical College \& Hospitals - Karaikal India \\ ${ }^{3}$ Dept of Medicine, Rajah Muthiah Medical college, Chidambaram India
}

\begin{abstract}
Objectives: To diagnose patients with Systemic lupus erythematosus clinically and compare various immunological tests available to detect their specificity and sensitivity of the various parameters employed.

Methods: It was hospital based cross sectional study. All patients satisfying the revised American College of Rheumatology criteria (1982) for SLE were included in the study over a period of 3 years. A total of two hundred and four individuals were included. The patients were divided into three groups- (Group I- Confirmed SLE patients-32, Group II- Incomplete SLE patients- 60, and Group III -patients with other autoimmune disorders- 42) and 70 persons were included as controls

Results: The patients were divided into three groups I,II,III and their clinical \& laboratory features were compared. Females (90.6\%) were more affected than males $(9.4 \%)$ and $69 \%$ were in the age group of $20-40$ years. The average age of onset of disease was 24.4 years. Predominant clinical features were arthritis $(81.25 \%)$, skin rashes $(72 \%)$, myalgia $(68.75 \%)$, alopecia $(68.75 \%)$, fever $(65 \%)$ and oral ulcers $18(56.25 \%)$. Anti-ds-DNA test and ANA test were positive in all the patients and the anti-DNP test was positive in 59.3\% patients.

Females were more affected (81.7\%) than males (18.3\%). 85\% were between $21-50$ years The average age of patients was 30.16 years with a range of $10-70$ years. Patients were regularly followed up and 32 patients $(26.67 \%)$ developed complete SLE. The most common manifestations were arthritis (88.3\%), fever (43.3\%) skin rashes (68.3\%). 10.34\% of ILE patients developed full SLE and all were females. Average age of disease onset was 24years.Anti-ds-DNA antibodies was detected in 28 patients (23.4\%), ANA in (25\%) patients and AntiDNP antibodies in $12(10 \%)$ patients.

Females $(81 \%)$ were affected than males $(19 \%) .86 \%$ were between $21-50$ years. The average age of patients was 33.24 years. The predominant clinical features were arthritis (78.6\%) and myalgia (76.2\%). Anti-ds-DNA antibodies were detected in 6\%, ANA in 35.7\% patients \& Anti-DNP antibodies in 3.6\%. Antibodies to ds-DNA were present in low titers in this group.

Conclusion: A clear separation between SLE and other autoimmune disorder was found with the anti-ds-DNA test. It has a high specificity for the differential diagnosis of SLE. Our study, comparing three assays with respect to their ability to predict disease activity, indicated that ds- DNA ELISA is the best method.
\end{abstract}

Keywords: Autoantibodies,Systemic Lupus Erythematosus, SLE, ANA, Ds-DNA, Lupus

\section{Introduction}

Systemic lupus erythematosus (SLE) is an immunological disorder with multi system involvement. It is a disease of unknown etiology in which tissues and cells are damaged by autoantibodies and immune complexes. SLE primarily affects young women and is estimated to occur in as much as $0.1 \%$ of the population. ${ }^{[1]}$

The discovery of LE cell by Hargreaves et al $(1948)^{[2]}$, Antinuclear antibody (ANA) by Meischer et al (1953) [3] and antibody to double stranded deoxyribonucleic acid (dsDNA) by Cepellini R, et al $1957^{[4]}$, Robbins WC, et al $1957^{[5]}$ led to a greater recognition of the milder cases and to a marked increase in its reported frequency.
ANA's are family of autoantibodies, which may be directed against nuclear antigens like double stranded-DNA (dsDNA), nuclear RNA, extractable nuclear antigens (ENA) and histones ${ }^{[6]}$ ANA is a good screening test for SLE because $95 \%$ of cases show a high titre (1:80 or more) of this autoantibody ${ }^{[6]}$. ANA may be positive in other rheumatic disorders such as systemic sclerosis, Sjogren's syndrome, overlap syndrome, antiphospholipid syndrome, polymyositis and rheumatoid arthritis. ${ }^{[6]}$

Antibodies to ds-DNA are found in the sera of SLE patients, and are considered as a marker of disease activity. ${ }^{[7]}$ These antibodies are considered to be of diagnostic significance and also of great prognostic value ${ }^{[8]}$ especially during 
clinical follow up. The ds- DNA antibodies level tend to fluctuate with the course of the disease ${ }^{[9]}$ and may act as a predictor of disease activity and exacerbation. ${ }^{[10]}$ The present study was to diagnose patients with SLE at Rajah Muthiah Medical College and Hospital, Chidambaram clinically and compare with various immunological tests available and also to detect their specificity and sensitivity of the various parameters employed.

\section{Materials and Methods}

The study was conducted in Department of Microbiology in collaboration with Department of Medicine, Rajah Muthiah Medical College and Hospital, Annamalai University, Chidambaram. The study period was spanned for a period of twenty two months. A standardized proforma was followed regarding the clinical history, general physical examination and laboratory tests done during the study period.A total of one hundred and thirty four individuals were included in this study (confirmed SLE-32, Incomplete SLE- 60, and other autoimmune disorders- 42 ) and 70 persons were included as controls at Rajah Muthiah Medical College \& Hospital, Tamilnadu, India.

The patient group was further divided into Group I-Sera from 32 patients with SLE (All patients met the 1982 American College of Rheumatology for SLE (updated 1997), fulfilling at least 4 of the 11 ARA criteria's). ${ }^{[11]}$ Group II- consists of 60 clinically suspected SLE patients who didn't fulfill at least 4 of the 11 ARA criteria's. Group III- 42 individuals having autoimmune disorders other than SLE. Patients having Rheumatoid arthritis (RA), Mixed Connective Tissue Disorders (MCTD), Scleroderma ( $\mathrm{Scl}$ ), Chronic Active hepatitis (CAH) were included in this group.

Clinical Examination: The diagnosis of SLE was made in patients because of the presence of at least four of the eleven criteria of the American College of Rheumatology (ACR). The Dermatologists, Physicians, carried out clinical examination and the clinical findings were recorded. The inpatient and outpatient medical records were carefully reviewed for other details such as age, sex, occupation, and socioeconomic status. Examinations of the patients were done according to the criteria's given in the 1997 revised ACR criteria for classification of systemic lupus erythematosus. The criteria included: mucocutaneous lesions (malar rash, discoid rash, photosensitivity, and oral ulcers); inflammatory arthritis; serositis (pleuritis; pericarditis, peritonitis); nephritis; neuropsychiatric disorders (seizure, psychosis, organic brain syndrome, and chorea), blood changes, immunological changes, abnormal titre of antinuclear antibody (ANA). At least 4 of 11 criteria must be present to diagnose SLE clinically.
Blood was collected from patients and controls and serum was separated as by the standard procedure and aliquoted into $1 \mathrm{ml}$ sterile plastic vials and stored at $-20^{\circ}$ C. Laboratory investigations were done which included immunological assays- anti-ds-DNA test, ANA, anti-DNP test, LE cell test, Rheumatoid factor (RF), C-reactive protein (CRP), full blood cell count, coagulation tests, routine biochemical and lipid profile, urine analysis, and 24 hour proteinuria. The following immunoassays were performed using commercially available kits:

Anti-ds-DNA antibodies test by ELISA, Antinuclear antibodies (ANA) by ELISA and Antideoxyribonucleoprotein (Anti-DNP), Rheumatoid factor (RF), C-reactive protein (CRP) by slide test by latex agglutination method.

Statistical analysis: Sensitivity, specificity, positive predictive value (PPV), negative predictive values (NPV) was calculated by using standard formulae.

\section{Results}

The age and the sex distribution of the patient groups are given in the table 1 .

And the clinical and the laboratory features in the patient groups were classified according to the 1982 revised criteria and are shown in the table 2 and the results of the immunodiagnostics tests in the patient groups and the controls are shown in the table 3

\section{Discussion}

The importance of antibodies to ds-DNA in the diagnosis and management of SLE has been universally recognized and used in daily clinical practice. The regional variation in the presentation of SLE is related to different genetic and environmental influences. ${ }^{(12)}$

Immunological Profile in Controls: In our study all the controls were negative for anti ds-DNA antibodies; $6 \%$ were positive for ANA and 5.7\% were positive for antiDNP antibodies which was higher than as reported by Burlingame RW and Cervera R. 2002. ${ }^{[13]}$

Studies have shown different prevalence of auto antibodies in healthy populations and they are always found in lower titers than those detected in autoimmune diseases. ${ }^{[14,15,16]}$ Sera of healthy adults especially females display a high frequency of ANA. ${ }^{[17]}$

In Group-I : Females (90.6\%) were more affected than males $(9.4 \%)$ and $69 \%$ were in the age group of $20-40$ years. The average age of onset of disease was 24.4 years with a range of 10-56 years. The female to male ratio was 9.6:1.Masi et al $1978^{[18]}$ reported an average male to 
Table 1: Age and Sex distribution of patient groups.

\begin{tabular}{|c|c|c|c|c|c|c|c|}
\hline $\begin{array}{l}\text { Patient } \\
\text { group }\end{array}$ & $\begin{array}{l}\text { Total } \\
\text { number }\end{array}$ & $\begin{array}{l}\text { Av Ds onset } \\
\text { yrs }\end{array}$ & $\begin{array}{l}\text { M:F } \\
\text { ratio }\end{array}$ & $\begin{array}{l}\text { Age group } \\
\text { (Yrs) }\end{array}$ & $\mathbf{M}$ & $\mathbf{F}$ & Total \\
\hline \multirow{6}{*}{ I } & \multirow{6}{*}{32} & \multirow{6}{*}{24.4} & \multirow{6}{*}{$1: 9.6$} & $10-20$ & 1 & 2 & $3(9 \%)$ \\
\hline & & & & $21-30$ & 0 & 13 & $13(41 \%)$ \\
\hline & & & & $31-40$ & 0 & 9 & $9(28 \%)$ \\
\hline & & & & $41-50$ & 1 & 3 & $4(13 \%)$ \\
\hline & & & & $51-60$ & 1 & 2 & $3(9 \%)$ \\
\hline & & & & Total & 3 & 29 & 32 \\
\hline \multirow{6}{*}{ II } & \multirow{6}{*}{60} & \multirow{6}{*}{30.16} & \multirow{6}{*}{$1: 4.5$} & $10-20$ & 2 & 4 & $6(10 \%)$ \\
\hline & & & & $21-30$ & 3 & 11 & $14(23 \%)$ \\
\hline & & & & $31-40$ & 5 & 16 & $21(35 \%)$ \\
\hline & & & & $41-50$ & 1 & 15 & $16(27 \%)$ \\
\hline & & & & $51-60$ & 0 & 3 & $3(5 \%)$ \\
\hline & & & & Total & 11 & 49 & 60 \\
\hline \multirow{6}{*}{ III } & \multirow{6}{*}{42} & \multirow{6}{*}{33.24} & \multirow{6}{*}{$1: 4.25$} & $10-20$ & 1 & 1 & $2(5 \%)$ \\
\hline & & & & $21-30$ & 2 & 7 & $9(20 \%)$ \\
\hline & & & & $31-40$ & 2 & 12 & $14(33 \%)$ \\
\hline & & & & $41-50$ & 3 & 11 & $14(33 \%)$ \\
\hline & & & & $51-60$ & 1 & 2 & $3(9 \%)$ \\
\hline & & & & Total & 9 & 33 & 42 \\
\hline
\end{tabular}

The results of the comparison of clinical features of patients group I, II, III are given in the table 2.

Table 2: Comparison of Clinical features of patients group I, II, III.

\begin{tabular}{|l|c|c|c|}
\hline Clinical features & $\begin{array}{c}\text { Group I (\%) } \\
\mathbf{N = 3 2}\end{array}$ & $\begin{array}{c}\text { Group II (\%) } \\
\mathbf{N = 6 0}\end{array}$ & $\begin{array}{c}\text { Group III (\%) } \\
\text { N= 42 }\end{array}$ \\
\hline Arthritis & 81.25 & 88.3 & 78.6 \\
\hline Skin rashes & 72 & 68.3 & 9.5 \\
\hline Photosensitivity & 43.75 & 10 & 05 \\
\hline Alopecia & 68.75 & 20 & 12.5 \\
\hline Oral ulcers & 56.25 & 6.67 & - \\
\hline Fever & 65.6 & 43.3 & 12.5 \\
\hline Lymphadenopathy & 37.5 & 35 & 22.6 \\
\hline Cardiac involvement & 12.5 & 2.5 & 1.2 \\
\hline Pulmonary involvement & 18.75 & 05 & 22.6 \\
\hline Raynaud phenomenon & - & - & 4.8 \\
\hline Myalgia & 72 & 54.2 & 76.2 \\
\hline $\begin{array}{l}\text { Neuropsychiatric } \\
\text { manifestations }\end{array}$ & 12.1 & 1.7 & - \\
\hline
\end{tabular}

Table 3: Results of immunodiagnostic tests.

\begin{tabular}{|l|l|l|l|l|l|l|}
\hline \multirow{2}{*}{$\begin{array}{l}\text { Patients, } \\
\text { Controls }\end{array}$} & Anti ds-DNA & ANA test & \multicolumn{2}{l|}{ Anti-DNP } \\
\cline { 2 - 7 } & Positive (\%) & $\begin{array}{l}\text { N Negative } \\
(\%)\end{array}$ & Positive (\%) & $\begin{array}{l}\text { Negative } \\
(\%)\end{array}$ & $\begin{array}{l}\text { Positive } \\
(\%)\end{array}$ & $\begin{array}{l}\text { Negative } \\
(\%)\end{array}$ \\
\hline Controls & $0(0)$ & $70(100)$ & $4(6)$ & $66(94)$ & $6(4)$ & $66(94)$ \\
\hline Group-I & $32(100)$ & 0 & $32(100)$ & 0 & $19(59.3)$ & $13(40.7)$ \\
\hline Group-II & $28(23.4)$ & $92(76.6)$ & $30(25)$ & $90(75)$ & $12(10)$ & $108(90)$ \\
\hline Group-III & $5(6)$ & $79(94)$ & $30(35.7)$ & $54(64.3)$ & $3(3.6)$ & $81(96.4)$ \\
\hline
\end{tabular}


female ratio of 1:5.5, Paul et al $2003^{[19]}$ had reported male to female ratio of 1:19 and Malaviya et al $1988{ }^{[20]}$ had reported a male to female ratio of 1:8.

The peak incidence was seen in the third decade. Similar observations were made by Malaviya et al $1988^{[20]}$ and Vaidya et al $19977^{[21]}$ but Masi and kaslow $1978^{[22]}$ observed a median age of disease onset at 31 years. In a study conducted by Paul et al $2003{ }^{[19]}$ in Kerala median age of disease onset was 21.6 years. Predominant clinical features were arthritis $(81.25 \%)$, skin rashes $(72 \%)$, myalgia (68.75\%), alopecia (68.75\%), fever (65\%) and oral ulcers $18(56.25 \%)$ patients.

In our study Anti-ds-DNA test and ANA detected antibodies in all the patients who were clinically diagnosed as SLE according to the ARA criteria and the anti-DNP test detected only in $59.3 \%$ patients.

Detection of ANA is a fundamental laboratory test for diagnosing systemic autoimmune diseases. Currently the method of choice is indirect immunofluorescence (IIF) on Hep-2 cell substrate. ${ }^{[23]}$ but now ELISA is also used as an alternative-screening test to IIF for detection of ANA. ANA-EIA is not only sensitive and specific compared to IIF using Hep-2 cells. ${ }^{[24]}$ but also objective, easy to perform and also less labor intensive when screening a large number of clinical specimens for ANA, but none of them are 100\% sensitive. ${ }^{[24]}$

Antibodies to ds-DNA are considered as a marker of disease activity for $\mathrm{SLE}^{[7]}$, they are not only considered to be of diagnostic significance and also of prognostic value. ${ }^{[8]}$ The detection of anti ds-DNA is one of the diagnostic criteria for SLE according to the American College of Rheumatology (ACR). Measurement of antiDNA antibody activity has become a routine laboratory procedure of value in diagnosing and managing patients with SLE. Fluctuations in antibody level tend to correlate with course of the disease. ${ }^{[9]}$ Several reports have also studied the changes in anti-ds-DNA antibody level instead of absolute values and find that increases in anti-ds-DNA antibody level may act as a predictor of disease activity and exacerbation. ${ }^{[10]}$ Patients with significant rise in anti-ds DNA antibodies at were more likely to have renal disease than those who did not. ${ }^{[25]}$ In our study all the patients in this group had high titres of anti ds-DNA antibodies. Antideoxyribonucleoprotein (anti-DNP) antibodies are found in approximately $75 \%$ of people with systemic lupus erythematosus. ${ }^{[13]}$

Group II of suspected SLE cases: Females were more affected (81.7\%) than males (18.3\%). 85\% were between 21-50 years. The average age of patients was 30.16 years with a range of 10-70 years. The female to male ratio was 4.5:1.

Incomplete lupus erythematosus (ILE) patients were regularly followed up and out of these only 32 patients (26.67\%) developed complete SLE. This is much higher than the study done by Greer and Panush in $1989^{[26]}$, who noted only $5 \%$ of the ILE patients, developed complete SLE.

Arthritis (88.3\%) was seen as the commonest manifestation similar to the observation made by Swaak et al 2001. [27] This is much higher than that reported by Greer and Panush (47\%). Fever was present in $43.3 \%$ of patients in our study. Dermatological manifestations like skin rashes, photosensitivity, oral ulcers and alopecia was noted in $68.3 \%$ of patients. This is almost same as reported by Greer and Panush (61\%). ${ }^{[26]}$

In our study the most common haematological abnormality was anaemia (38.3\%) and most of them were normocytic normochromic anaemia. Lymphadenopathy was seen in $35 \%$ of the patients.

When compared with group I- confirmed SLE patients, ILE patients had fewer systemic manifestations. Clinical and serological manifestations of ILE patients were studied by Vila et al $2000{ }^{[28]}$ and according to them only $8.5 \%$ of the ILE patients when followed up developed complete SLE, but none with major organ damage but in our study $26.7 \%$ developed complete SLE. Malar rash and oral ulcers are less frequently seen ILE patients and they have less chances of developing photosensitivity and antibodies to ds-DNA. ${ }^{[28]}$ Patients with ILE had more of skin and musculoskeletal involvement and $18 \%$ of ILE patients developed full SLE. ${ }^{[27]}$ ILE patients have better prognosis than complete SLE. ${ }^{[27]} 10.34 \%$ of ILE patients developed full SLE and all were females. Average age of disease onset was lower in full SLE (24years) than those remained as ILE (34 years). ${ }^{[28]}$

In our study, in suspected SLE patients; anti-ds-DNA antibodies was detected in 28 patients $(23.4 \%)$ patients, ANA in $(25 \%)$ patients and Anti-DNP antibodies in 12 $(10 \%)$ patients.

When this group was followed during our study period, only 32 patients developed complete SLE and out of these 32 patients, 28 patients had positivity for anti-ds-DNA, 30 patients had positivity for ANA and 12 patients were positive for anti-DNP. Rest of the patients' signs and symptoms simulating SLE disappeared during the course of the treatment given.

Group III of Autoimmune Disorders Other than SLE Cases: Females (81\%) were affected than males 
(19\%).86\% were between 21-50 years. The average age of patients was 33.24 years with a range of $10-70$ years. The female to male ratio was 4.25:1.

The predominant clinical features were arthritis (78.6\%) and myalgia (76.2\%). In this group anti-ds-DNA antibodies were detected in $6 \%$ of the patients. ANA was detected in $35.7 \%$ patients. Anti-DNP antibodies were detected in $3.6 \%$. ANA are diagnostic markers for a variety of autoimmune diseases including rheumatoid arthritis, scleroderma, Sjogren's syndrome, SLE, autoimmune hepatitis. ${ }^{[17]}$

In SLE, antibodies to ds-DNA are present in high titers but they may be present in low titers in other rheumatic diseases. ${ }^{[29]}$ In our study, all the five patients who were antids-DNA positive were having low titers suggesting high specificity and discriminating power of this immunological test for SLE.

Comparison of clinical features of group I with group II and group III: In our study, females were more affected than males (1:9). Patients with renal disease had high titres of anti-ds-DNA levels and also had active disease. In group II, the age of disease onset is more (34 years) as compared to confirmed SLE (24.4 years). Multiple organ involvement was less commonly seen and male to female ratio was $1: 4.5$. The course of disease is mild as compared to group I and most of the patients responded to non-steroidal antiinflammatory drugs (NSAID).

\section{Conclusion}

In the present study a clear separation between SLE and other autoimmune disorder was found with the anti-ds-DNA test. It has a high specificity for the differential diagnosis of SLE. Due to availability of laboratory investigation there has been increased report of prevalence of SLE throughout the world. ELISA assay has been introduced as a sensitive method for detection of anti-ds-DNA Abs. This is based on the finding that by this technique both low and high avidity antibodies are detected. Our study, comparing three assays with respect to their ability to predict disease activity, indicated that ds-DNA ELISA is the best method. Advanced renal disease is now less common due to recognition of milder forms of the disease. Thus, the potential benefits of making the correct diagnosis of SLE at an early stage are obvious. We therefore recommend the measurement of anti ds-DNA antibodies wherever clinically appropriate regardless of the presence or absence of ANA.

\section{References}

1. Dobkin PL, Costa DD, Fortin PR, et al. Living with lupus: A prospective Pan-Canadian study. J Rheumatol 2001; 28:2442-2448
2. Hargreaves MM, Richmond H, Morton R : Presentation of two bone marrow elements: the 'tart' cell and the 'LE' cell. Proc Mayo Clin 23:25-30, 1948.

3. Miescher $\mathrm{P}$, Fauconnet $\mathrm{M}$, Berand $\mathrm{T}$ : Experimental immunonucleophagocytes and the LE phenomenon. Exp Med Surg 11:173-177, 1953.

4. Cepellini R, Polli C, Celada F : A DNA-reacting factor in serum of a patient with Lupus erythematosus diffusers. Proc. Soc Exp Biol Med 1957;96:572-576.

5. Robbins WC, Holman HR, Deicher H, Kunkel HG: Complement fixation with cell nuclei and DNA in Lupus erythematosus. Proc Soc Exp Biol Med 96:575-579, 1957.

6. Kumar A. Indian guidelines on the management of SLE. J Indian Rheumatol Assoc 2002:10:80-96.

7. Rahman MA, Isenberg DA. Autoantibodies in systemic lupus erythematosus. Curr Opin Rheumatol 1994; 6:468-73.

8. Pisetsky DS. Anti-DNA antibodies in systemic lupus erythematosus. Rheum Dis Clin North AM 1992;18:437- 54

9. Smeenk RJ, Van den Brink HG, et al. Anti-dsDNA: choice of assay in relation to clinical value. Rheumatol Int 1991;11:101-7.

10. Ter Borg EJ, Horst G, Hummel EJ, et al: Measurement of increases in anti double-stranded DNA antibody levels as a predictor of disease exacerbation in systemic lupus erythematosus. Arthritis and Rheum 1990;33:634-43.

11. American College of Rheumatologya (ACR 1999) Ad Hoc Committee on Systemic Lupus Erythematosus Guidelines. Guidelines for Referral and Management of Systemic Lupus Erythematosus in Adults. Arthritis Rheum 1999;42(9):1785-96.

12. Vila LM, Alarcon GS, McGwin G Jr et al. For the LUMINA study group. Early clinical manifestations, diseases activity and damage of Systemic Lupus Erythematosus among 2 distinct US Hispanic subpopulations. Rheumatology (Oxford) 2004; 43:358-363.

13. Burlingame RW, Cervera R. Anti-chromatin (antinucleosome) autoantibodies. Autoimmune Rev. Dec 2002;1(6):321-8.

14. Baig MM, Shere SJ. Prevalence of autoantibodies in Saudi population. J Med 1989; 20(3,4):286-90.

15. De Vlam K, De Keyser F, Verbruggen G, et al. Detection and identification of antinuclear autoantibodies in the serum of normal blood donors. Clin Exp Rheumatol 1993; 11(4):393-7.

16. Vazquez-Del Mercado M, Gonzalez-Bernaldez M, GarciaDe La Torre I. Prevalence of antinuclear antibodies in a Huichol population of Mexico. Lupus 1995; 4(2):164-5.

17. Teubner A, Tillmann HL, Schuppan D, et al. Prevalence of circulating autoantibodies in healthy individuals. Med Klin (Munich). 2002 Nov 15;97 (11):645-9.

18. Masi AT, Kaslow RA. Sex effects in systemic lupus erythematosus: a clue to pathogenesis. Arthritis Rheum. 1978;21:480-484. 
19. Paul BJ, Muhammed Fassaludeen, Nandakumar, MV Razia. Clinical profile of Systemic lupus erythematosus in Northern Kerala. J Indian Rheumatol Assoc 2003:11:94-97.

20. Malaviya AN, Singh RR, Kumar A, De A et al. systemic lupus erythematosus in northern India: A review of 329 cases. J Assoc Physicians India 1988;36:476-480.

21. Vaidya S, Samant RS, Nadkar MY, Borges NE. Systemic lupus erythematosus- a review of 220 patients. J Indian Rheumatol Assoc 1997; 5: 14-18.

22. Masi AT, Kaslow RA. Sex effects in systemic lupus erythematosus: a clue to pathogenesis. Arthritis Rheum. 1978;21:480-484.

23. White $\mathrm{R} \mathrm{H}$, and D L R obbins. Clinical significance and interpretation of antinuclear antibodies. West J Med. 1987. 147:210-213.

24. Jaskowski TD, Schroder C, Martins TB et al. Screening for antinuclear antibodies by enzyme immunoassays. Am J Clin Pathol. 1996 Apr;105(4):468-7.
25. Arbuckle MR, James JA, Kohlhase KF, et al. Development of anti- dsDNA autoantibodies prior to clinical diagnosis of systemic lupus erythematosus. Scand J Immunol.Jul-Aug 2001;54(1-2):211-9.

26. Greer JM and Panush RS. Incomplete lupus erythematosus. Journal Watch (General) 1989:2-2

27. Swaak AJ, van de Brink H, Smeenk RJ, et al. Incomplete lupus erythematosus: results of a multicentric study under the supervision of the EULAR Standing Committee on International Clinical Studies Including Therapeutic Trials (ESCISIT). Rheumatology (oxford). 2001 Jan;40(1):89-94.

28. Vila LM, Mayor AM, Valentin AH, et al. Clinical outcome and predictors of disease evolution in incomplete lupus erythematosus. Lupus. 2000;9(2):110-5.

29. Notman DD, Kurata N,Tan EM. Profiles of antinuclear antibodies in systemic rheumatic diseases. Ann Intern Med. 1975 Oct;83(4):464-9.

*Corresponding author:

Dr. R. Latha, Dept of Microbiology Aarupadai Veedu Medical College \& Hospital, Pondicherry- 607403. INDIA

Phone: +91 9894155330

Email: latha.ragunathan@avmc.edu.in

Financial or other Competing Interests: None. 